\title{
Adult literacy in Aotearoa New Zealand: Policy, potential and pitfalls
}

\author{
Jane Furness and Judy Hunter \\ Wilf Malcolm Institute of Educational Research, University of Waikato
}

\begin{abstract}
Policy aimed at increasing adult literacy and numeracy skills has been a strong focus of the New Zealand Ministry of Education since the launch of More than Words: The New Zealand Adult Literacy Strategy in 2001. This policy and the foundation learning strand in consecutive Tertiary Education Strategies since 2002 have involved significant sector investment. This article examines the current state of adult literacy policy, its trajectory, potential, and pitfalls. Applying a sociomaterial perspective, we explore how the discourse of adult literacy is well embedded in dominant ideologies of individual responsibility and entrepreneurialism. We argue that interest in other perspectives that offer the hope of a more inclusive society must be supported through broad dissemination of alternative material text and artefacts.
\end{abstract}

Keywords: literacy education, literacy policy, adult education

\section{Introduction}

Results of New Zealand's participation in the 1996 International Adult Literacy Survey and subsequent waves of Organisation for Economic Co-operation and Development sponsored surveys showed that a large portion of the population did not meet "a suitable minimum for coping with the demands of everyday life and work in a complex, advanced society" (Organisation for Economic Co-operation and Development, 2000, p. xi). In response, literacy education emerged strongly in tertiary education policy in New Zealand heralding a period of considerable infrastructural development in adult literacy education, the bulk of which occurred between 2002 and 2012.

The purpose of this article is to review New Zealand adult literacy policy in place in 2016 to provide a critical perspective on its intentions, aspirations, and limitations. We interrogate current policy and its trajectory, potential, and pitfalls. Our aim is to provide a theory-based investigation into official adult literacy policy in New Zealand and its uptake in the education sector and broader society that can serve as a rigorous starting point for further discussion and critique. Whereas we applaud government's commitment to adult literacy and numeracy, we find several aspects of the policy to be problematic. These include the narrowly based human capital approach centring on literacy and numeracy for employment and the Organisation for Economic Co-operation and Development standardised testing scheme, with its adaptation in our high-stakes national assessment programme (the Literacy and Numeracy for Adults Assessment Tool) and our educational practices. As well, a series of international Organisation for Economic Co-operation and Development adult literacy surveys has depicted a deficit image of adults based on test results, which is buttressed and justified in New Zealand through a recent policy shift to limited government "investment" in those identified as responsible, entrepreneurial individuals. 


\section{Theoretical framework}

This paper draws on a sociomaterial approach to literacy which brings in the theory of literacy as social practice. In a sociomaterial approach, educational policies such as those pertaining to adult literacy education are seen as projects of social ordering involving technologies of governance (Hamilton, 2016). Fundamental to a sociomaterial approach is a shift away from solely personal human meanings in literacy practices to include recognition of the material to include all elements as "mutually constituted" in whole systems (Fenwick, 2010, p. 107). Thus, we examine New Zealand policies from this broad perspective to illuminate how literacies are assembled through public discourses and materialised through everyday policy and its enactment. Specifically, we draw on processes of reification and on critical discourse analysis.

Reification involves the instantiation of the abstract (e.g., ideas, theories, ideologies) as a concrete entity, for example, a material artefact such as a document (Barton \& Hamilton, 2005). Materiality both stabilises and distances the abstract from underlying structural, historical, and social forces (Chari, 2013). Moreover, the process of reification through materialisation helps reinforce social hierarchies. Reified ideologies can easily become normalised, accepted as natural, and inconvertible (Pahl, 2014). Reification, then, can also have a depoliticising, disengaging effect on individuals in sociopolitical contexts (Chari, 2013). Government agendas are reified in part through the written codification of policy documents. These documents serve as material artefacts whose meanings can be recontextualised, shaped through sociopolitical networks, and reassembled in the discourses of literacy education.

Critical discourse analysis offers a tool and an approach to interpreting and explaining how texts work in social and historical contexts. It assumes that texts are socially and politically constituted. It attends to issues of power and ideology as reflected in both print and multimodal texts. Fairclough $(1989,2003)$ identifies three key features in the practice of critical discourse analysis: text description; interpretation drawing on the contextual situatedness of the text; and explanation of how it links to broader social structures, ideologies and power relations. In this article, we will focus on making sense of the underlying messages about adult literacy and numeracy by examining the discourses of major government policy documents, their pedagogical presence in the National Centre of Literacy and Numeracy for Adults and Ako Aotearoa websites, and policy developments presented at the 2016 National Centre of Literacy and Numeracy for Adults Symposium. We will also analyse several other documents and recorded presentations to show how the discourses of policy are broadly disseminated and materialised throughout the sector. Our aim is not to present a comprehensive overview of the literature and numeracy literature influential in 2016 policy and practice, but to explicate the dominant policy discourse and illustrate how it is codified and reified across the sector as a "common-sense" response to adult learning needs.

\section{Modes of inquiry}

We reviewed major adult literacy policy documents, along with related government publications, and professional development guides and reports, illustrating how government 
policy discourses are assembled, articulated and materialised throughout the enactment of adult literacy policy.

Key policy documents identified as relevant to our consideration of the state of adult literacy policy in 2016 are the Tertiary Education Strategy 2014-2019 (Ministry of Business, Innovation and Employment \& Ministry of Education, 2014) and the Literacy and Numeracy Implementation Strategy 2015-2019 (Tertiary Education Commission, 2015). The Tertiary Education Commission's (2009) Strengthening literacy and numeracy: Theoretical framework is also important for the explanation it provides about the theory behind adult literacy policy. Other reports provide an articulation of policy beyond official documents. In particular, two presentations at the 2016 National Centre of Literacy and Numeracy for Adults Literacy and Numeracy Symposium provide insights. The first is David Do and Kathryn Hazlewood's Literacy and Numeracy Update, and the second, New Zealand in the International Survey of Adult Skills (Programme for the International Assessment of Adult Competencies) by William Thorn, Education Directorate, Organisation for Economic Co-operation and Development. We were unable to find recent reviews, other recent research or critical opinion pieces. As part of their function, the Ako Aotearoa and National Centre of Literacy and Numeracy for Adults websites share information about policy and practice and promote learning opportunities for adult literacy educators. In these roles, they re-articulate policy and provide instances of, and support for, particular forms of government-sanctioned policy implementation.

\section{Background}

Despite long-held concerns expressed by community-based education providers (Benseman, 2008), adult literacy did not come into sharp focus for government until the results of the 1996 International Adult Literacy Survey showed that, on this measure, over a million New Zealand adults were below the level thought necessary for social and economic participation in a knowledge-based society (Walker, Udy, Pole, May, Chamberlain, \& Sturrock, 1997). These results were deeply concerning for government because the dominant view at the time was that economic and social progress would be stymied if there were not enough adults with the literacy skills needed in the business world and the worlds of industry and enterprise (Organisation for Economic Co-operation and Development \& Statistics Canada, 2000). The subsequent intense infrastructural development has continued, reinforced through literacy policy and implementation plans that demonstrate government's ongoing commitment to raising literacy levels (Tertiary Education Commission, 2008, 2015).

From the outset, adult literacy policy has focused strongly on English language-based literacy skills of functional value in life and work. The concept of multiple literacies and multiple modes (e.g., multiple languages and text forms such as graphics, sound, geographical features of tribal lands) of literacy have been recognised to some extent but not given primacy (see, for example, Māori Adult Literacy Working Party, 2001). Both economic and social reasons for raising adult literacy levels are repeatedly mentioned, but over time, economic rewards remain the main driver of the literacy work. Context is recognised as important in literacy learning and there is support for culturally appropriate pedagogy. Together these approaches have the potential to embody a valuing of different ways of being people in the world (Gee, 2008), but this is restricted by the emphasis on a narrow conception of literacy and its purposes. Furness (2012) concludes that "there is ... a sense in which only lip service is paid to deeper meanings of literacy and its association with identity and what that might 
mean for non-dominant groups" (p. 63). Against a backdrop of a persistent narrow view of literacy, levels of adult skills and the numbers of adults with apparently low levels of skills are used as evidence supporting the idea that there is a particular problem with adult literacy that must be addressed in particular ways.

\section{The Tertiary Education Strategy}

The overarching document influencing adult literacy education efforts in 2016 was the Tertiary Education Strategy 2014-2019 which set out the government agenda for tertiary education overall for this six-year period (Ministry of Business, Innovation and Employment \& Ministry of Education, 2014). In his foreword to this key document, the Minister for Education, Skills and Employment begins by stating:

Tertiary education helps improve people's lives, and the lives of those around them. It is a passport to success for individuals in our society, and supports wider economic growth and prosperity. Skilled people are essential to the success of business and other organisations. (p. 2)

More formally, the 2014 Tertiary Education Strategy claims in its introduction that "tertiary education offers a passport to success in modern life ... helps people improve their lives and the lives of those around them, ... provides the specific tools for a career, and is the engine of knowledge creation" (p. 3). In these personal and official ministerial messages, claims are made for the transformative power of education with which few would argue as a general principle. Simultaneously imbued with a focus on individuals, skills, careers, business growth and economic prosperity, however, the value of literacy in the rich dimensions of people's full lives is hard to see. People are positioned as instrumental in providing skills for a progressive economy that will, in unstated ways, improve their lives but, at the same time, as currently unable to adequately fulfil that function. Further, with no explanation of what "success in modern life" and "improv(ing) their lives and the lives of those around them" might mean, readers who value a dynamic family, community and cultural life alongside a working life could be forgiven for not recognising themselves in this agenda.

The state of tertiary education in New Zealand is presented in the 2014 Tertiary Education Strategy as improving as a result of the government's approach. This approach has centred on the development of a single learner record and the New Zealand Qualifications Framework. These tools are presented as "providing a common language for recording learners' progress through schools and tertiary education organisations", enabling enhanced targeting of need (Ministry of Business, Innovation and Employment \& Ministry of Education, 2014, p. 5) in line with the social investment strategy discussed below. Again, need is connected to global business competitiveness and growth of the New Zealand economy. Whereas institutions and qualifications bodies bear some responsibility for learner improvement, under the individualised social investment policy, responsibility for showing they are worthy of investment also lies with learners. In fact, institutions may pressure unsuccessful individuals to offset blame on themselves. The strong message of individual responsibility is also present as the government's approach is described as providing "opportunities" for people to "improve their own social outcomes by gaining the skills they need to become successful and productive citizens" within this expanded economy (p. 7). 
Again, skills in and of themselves are assumed to improve people's lives, and good citizens will take up the opportunity to gain them. Increases in participation, more graduates and greater value for money within the system are evident in the data the government now collects, the Tertiary Education Strategy claims. We are warned, however, that still more global connectedness, more connection between education and industry and more citizen participation in higher level learning are required for prosperity for all. Improving adult literacy and numeracy is the fourth of six priorities within the Tertiary Education Strategy aimed at achieving this.

The definition of literacy underpinning government adult literacy policy was reconfirmed in 2016 via the Literacy and Numeracy Implementation Strategy (Tertiary Education Commission, 2015) which refers, in turn, to the theoretical framework underpinning the government's literacy work set out by the Tertiary Education Commission in 2009. Here, a person's literacy is described as "the extent of their written and oral language skills and knowledge and their ability to apply these to meet the varied needs of their personal, study and work lives" (p. 58). The Tertiary Education Strategy Priority 4: Improving adult literacy and numeracy argues that without basic literacy, language and numeracy skills, "adults are limited in all aspects of their lives including finding and keeping a job, raising their children, and following instructions" (Ministry of Business Innovation and Employment \& Ministry of Education, 2014, p. 15). Examples of instructions given are for the safe use of medicines, the preparation of food and workplace health and safety. This linking of low literacy levels with inadequacies as an employee, parent and independent human being seems to us to sum up the multifaceted way people are cast as deficient across every aspect of their lives. Emphasis is then placed in the 2014 The Tertiary Education Strategy on the need for the literacy, language and numeracy skills for the achievement of qualifications and improved career prospects "which can lead to more productive, better paid and sustainable employment" (p. 15). Here we again see ideas about what is important in life limited to work.

In 2016, specifically literacy-focused policy thereby reflects the overall Tertiary Education Strategy approach of targeted interventions. The Literacy and Numeracy for Adults Assessment Tool provides data that enables increasingly refined targeting of programme provision, couched in terms of offering diverse and flexible learning options that reflect people's differing literacy and numeracy needs and that "help support their achievement" (p. 15). On the one hand, it could be argued that targeting in this way demonstrates both care for those most in need and fiscal responsibility on the part of government. However, it seems to us to be quite powerful surveillance of, and interference in people's lives based on a reification of particular forms of human capital for particular purposes, as shown in the policy and strategy documents discussed here.

\section{The literacy and numeracy implementation policy}

The intended purpose of the Literacy and Numeracy Implementation Strategy 2015-2019 is to give effect to the policy set out in the Tertiary Education Strategy. The indicators of success are threefold (Tertiary Education Commission, 2015). The first is increased Level 2 and above course completion rates and more people achieving Level 2 or above qualifications. The second is improvement in adult literacy, language and numeracy skills as measured by increased rates of "full and effective" use of the Literacy and Numeracy for Adults Assessment Tool and increased rates of adults who achieve statistically significant gain. The third indicator 
is more industry involvement with tertiary education, measured through more learners and employers involved in workplace literacy and numeracy programmes and more industry trainees completing Level 2 qualifications (Tertiary Education Commission, 2015, p. 8). Number targets have been set for each of these indicators. Work designed to achieve these targets includes: enhanced focus on workplaces and collaborating with other agencies; more support for Māori, Pacific and young people, new migrants and people with learning difficulties; maintaining and promoting resources the Tertiary Education Commission develops for tutors' use and maintaining and supporting a well-qualified workforce; and sharing knowledge and resources with the Ministry of Education.

Most noticeable to us is the failure of the Implementation Strategy to meaningfully embed Haea te pū ata: A national strategy for Māori adult literacy and numeracy 20162020 (and beyond) (Hutchings \& Ikin, n. d.). This significant work reflects Māori values, realities and aspirations in the $21^{\text {st }}$ century. It sets out priorities and implementation steps for the five years from 2016 to 2020, demonstrating their alignment to key government documents: government's Better Service Targets, the Tertiary Education Strategy's strategic goals and the key strategic goals of He kai kei aku ringa: The Crown-Māori Economic Growth Partnership (Māori Economic Development Panel, 2013).

It is possible to see Haea te pū ata's inclusion in the Implementation Strategy's four streams of work. For example, Workstream 1, which is aimed at "reach [ing] more people" by "increasing our focus on the workplace" and "collaborating with other agencies", mentions "work[ing] with agencies involved in Māori development initiatives such as Whānau Ora" (Tertiary Education Commission, 2015, p. 10-11). It also mentions a potential campaign to reduce stigma and promote solutions that might focus on whānau (along with "employers and other particular groups in society") (p. 11). Workstream 2 is aimed at "better target[ing] support to individual learners" in the priority groups, including completing the Te Ata Hāpara reading option in the Literacy and Numeracy for Adults Assessment Tool and "consider[ing] and implement[ing] the recommendations of ... Haea te pū ata as resources allow" (p. 12). Workstream 3 refers to He Taunga Waka offered by Ako Aotearoa to provide resources and support a qualified workforce.

Thus some remnants remain, but overwhelmingly Haea te pū ata has been drawn into the discourse of the Implementation Strategy and has lost much of its cultural and historical force. Located here, it is open to interpretation by anyone who puts the general policy into action. In particular, the centrality of whānau wellbeing in Haea te pū ata - foundational to Māori aspirations - is severely weakened in the Implementation Strategy where the workplace predominates at the expense of a broader focus.

\section{The National Centre of Literacy and Numeracy for Adults and Ako Aotearoa websites}

These two websites have what may be the best known adult literacy and numeracy presence in New Zealand. The content of both aligns well with government perspectives. National Centre of Literacy and Numeracy for Adults operates under a contract with the Tertiary Education Commission to support adult literacy and numeracy policy implementation through providing information, activities, and resources for literacy and numeracy educators. Its website provides a forum for the dissemination of policy messages, information on how government expects the policy to be implemented, and resources for implementing policy and professional development. The website offers access to a literature portal with a broad 
range of international writing on adult literacy and numeracy. It also provides information on adult literacy and numeracy-related local and international journals and reports. The portal and the links to journals expose readers to wide-ranging viewpoints on literacy and numeracy theory, policy and practice that can foster critical reflection and debate about the New Zealand approach. However, primarily visitors to the site are met with information about the use of the literacy and numeracy strategy infrastructural tools as directed by policy. These tools include the Literacy and Numeracy for Adults Assessment Tool, for example, the Learning Progressions for Adult Literacy and Numeracy (a description of stages of literacy and numeracy skills learning) and Pathways Awarua (an interactive online programme for individual learners to improve their literacy and numeracy skills).

Notably, in introducing itself to its visitors, the website repeats the message of a deficient population that imbues the literacy policy and implementation documents, citing from the Tertiary Education Commission's (2013) Getting Results in Literacy and Numeracy, 2010-2013 report:

The scale of the literacy and numeracy challenge is significant and will take many years to address. Changing technology, international competition and globalisation mean the demands for a highly literate and numerate population are constantly increasing. Demographic trends and continuing migration mean a continuing flow of people into the cohort of those needing higher levels of literacy and numeracy if they are to reach their full potential. (p. 21)

Encouragingly, the website shows recognition of the importance of contexts in learning. It states that the National Centre of Literacy and Numeracy for Adults "promote[s] an embedded approach to literacy and numeracy which equips educators to identify literacy and numeracy needs and demands ... and supports adult learning in a range of contexts". However, the workplace predominates as the important context. Finally, it reports that the National Centre of Literacy and Numeracy for Adults supports existing and developing activity across New Zealand, especially with the tertiary education priority groups of Māori, Pasifika and youth. But, again, we are disappointed. We observe, for instance, that plans for how the National Centre of Literacy and Numeracy for Adults might work with and support Māori and Pasifika literacy enhancement efforts were developed in 2012 but what difference this has made is not evident to us in 2016 and appears, therefore, to be a continuation of lip service to differing cultural interpretations of what literacy is and what is needed to ensure participation in all the worlds that are important to people.

Ako Aotearoa: National Centre for Tertiary Teaching Excellence offers information about teaching and learning across the whole tertiary sector. Its strategy is framed, according to the website, in the context of the government's 2014-2019 Tertiary Education Strategy and the Māori education strategy: Ka Hikitia - Accelerating Success 2013-2017 (Ministry of Education, 2012). In 2016, He Taunga Waka delivered 45 free workshops around the nation to approximately 600 educators working in the foundation sector with Māori and Pasifika learners for whom it provides valuable resources. Focusing particularly on teaching and learning, Ako Aotearoa does not, however, overtly challenge the standard discourse of workrelated purposes for literacy learning.

\section{The investment approach to adult literacy and numeracy education}

The annual National Centre of Literacy and Numeracy for Adults Symposium, sponsored by the Tertiary Education Commission, serves adult literacy and numeracy professionals across 
the country at no cost. It enables practitioners to share good practices in the field and provides a forum for the delivery of the Tertiary Education Commission's policy updates. In line with our interest in policy, we have focused on government policy announcements in 2016. At the 2016 Symposium, the Tertiary Education Commission and Ministry of Education announced key strategy and policy development focussed on the investment approach to adult literacy and numeracy education, its goals, implementation plans, and current initiatives. The investment approach, a social policy direction taking various forms, has been established internationally since the 1990s and more recently in New Zealand. The Treasury's (2016) statement describes it as:

- improving the lives of New Zealanders by applying rigorous and evidence-based investment practices to social services;

- using information and technology to better understand the people who need public services and what works, and then adjusting services accordingly. What is learnt through this process informs the next set of investment decisions;

- focuss[ing] on early investment to achieve better long-term results for people and helping them to become more independent. This reduces the number of New Zealanders relying on social services and the overall costs for taxpayers. (para. 1-3)

The new approach, which consolidates many of the features discussed above in earlier documents, involves three improvement goals for: learner outcomes, social and economic outcomes, and system stewardship. The Tertiary Education Commission plans to achieve these goals through simplifying engagement for all, aligning measurement with outcomes, and rewarding educational organisations for providing better pathways and staircasing (Do \& Hazlewood, 2016). It maintains that the strategy will reach more people, individualise support for learners, influence other agencies, and ensure the capacity of tutors.

At the Symposium, the approach was characterised as a move away from the previous compliance-based model of funding, awarded as providers met regulations for learner progress on assessments, pass and completion rates. Nevertheless, the existing regulations continue and are reinforced, for the investment strategy relies on individualised meta-data, that is, literacy and numeracy results collected via mandated standardised Literacy and Numeracy for Adults Assessment Tool assessments by literacy and numeracy learners at the beginning and on completion of their courses. These assessment results serve as what the Tertiary Education Commission terms rigorous evidence to then adjust services. However, there are a number of similarities among the Literacy and Numeracy for Adults Assessment Tool and the Organisation for Economic Co-operation and Development surveys. According to Earle (2014), "the development team for the Assessment Tool drew on knowledge and experience from the ALL [Adult Literacy and Life Skills] survey" (p. 3), sharing similar context categories and testing methodology, for example. The Organisation for Economic Cooperation and Development literacy assessment schemes have been widely criticised, notably by Hamilton and Barton (2000) for example, who argued that the survey presents a partial picture of people's literacy competence and that the claims that the test questions reflect everyday literacy and numeracy cannot be substantiated. In this way, investment in literacy and numeracy education for individual learners will be determined by a limited assessment scheme.

Further, the policy, as outlined at the Symposium, leaves much unstated and unexplained, quite possibly due to time constraints of the presentation itself. However, in 
Jenson's (2009) view the social investment approach, as typical of multifaceted ideas, is most successfully disseminated when it is ambiguous enough to appear robustly developed while maintaining a common-sense appeal. The current strategy reflects these characteristics in several ways. First, it draws on euphemistic generic expressions that seem academically sound but are inexplicit (e.g., "system stewardship", "better pathways and staircasing"). Second, it appeals to traditional normative views of the deserving vs undeserving poor (i.e., those who are responsible citizens) and of responsible government (by saving taxpayer money). Third, it neglects to describe precisely how it will determine individual investments other than through assessments, which can heighten both educators' and learners' uncertainty and insecurity. With the current narrow focus on formal assessment outcomes, the policy so far appears not to take into account segments of the population who are unable to access employment, such as the sick or disabled (Cantillon \& Van Lancker, 2013). It also fails to recognise that many of those who do not behave "responsibly" may be constrained by personal circumstances such as lack of resources or family support. How such people will fare under the social investment scheme is unclear.

Other documents illustrate Hamilton's (2016) social ordering through technologies of governance. One example is Thomas, Johnston, and Ward's (2014) research report commissioned by the Tertiary Education Commission, which aligns several literacy benchmarks and measures: the proficiency levels in the Adult Literacy and Life Skills Survey; the Learning Progressions as measured in the Literacy and Numeracy for Adults Assessment Tool; the literacy and numeracy requirements for the National Certificate in Educational Achievement; and the New Zealand Curriculum national standards for reading and numeracy.

The paper makes useful comments on the alignment and highlights problems in that alignment. The paper does well what it sets out to do but does not set out to take a stance with regard to the ideology underlying the measurement of literacy and numeracy in the education system. There is no exposition of ideological context, so no opportunity for the reader to make a judgment - work like this appears neutral when it actually is not. In fact its focus on aligning literacy and numeracy standards internationally and nationally for both adult and school learners also facilitates and expands the meta-data approach to individualised social investment across all educational levels. In this sense, it depicts codified and reified documents that serve to maintain a system of social order across the education sector.

\section{Reassessing our direction}

The implications of the Organisation for Economic Co-operation and Development literacy survey results beginning in 1996 that depicted those scoring below Level 3 as incapable of functioning in the modern economy have become well known across the sector. A seminal example of reification that has reinforced social hierarchies, it has been widely repeated in subsequent reports, the media and adult education. However, a serendipitous question at the 2016 National Centre of Literacy and Numeracy for Adults Symposium (Thorn, 2016) evoked a heartening response from the plenary speaker. William Thorn (Senior Analyst, Organisation for Economic Co-operation and Development Directorate for Education and Skills) was asked to comment on the 2006 survey results, indicating that $43 \%$ of New Zealand adults were below the level needed for a modern economy. His response was clear: that the current survey eschewed such claims as they are "manifestly untrue." He affirmed that 
improvement in literacy and numeracy skills is advantageous to society, but also pointed out that at Level 3 and below, most people are employed, and that in Italy, a functioning modern economy, 60\% scored less than Level 2. The impact of Thorn's response is unclear at this point, for it lacks the dramatic appeal of the materialisation of the earlier claim, and it took the form of an unplanned oral comment. Nevertheless, it represents an important counter to the denigration of those with lower literacy assessment scores.

We think it is also timely to revisit the work of the Māori Adult Literacy Working Party which, in 2002, provided an important perspective on the meaning and purpose of literacy for Māori. Te kawai ora: Reading the world, reading the word, being the world (Ministry of Māori Development, 2002) highlighted the significance in our nation of embracing and celebrating a broad and inclusive interpretation of what it means to be a literate person that gives space for, and acknowledges, the critical contribution of many ways of being in the world. This message is one that needs to be foregrounded again.

\section{Conclusions}

Both the official and public discourse of literacies and their everyday materialisation are well embedded in dominant neoliberal ideologies of individual responsibility and entrepreneurialism. The role of government is seen to offer opportunities for marginalised groups to participate more fully in society. The codified and reified discourse of adult literacies embodies these neoliberal ideologies and is entrenched in social institutions like schools, business and industry and in the popular press.

There are some signs of interest in other perspectives. If we want to legitimise an alternative view, we need to challenge the dominant discourse and provide material text and artefacts to disseminate broadly. This paper is a new call for work of scholarly significance that is disseminated beyond the academic sector to business, industry, social institutions, and the community. Research might include work to broaden the scope of literacy and numeracy assessment. Examples include a current Teaching and Learning Research Initiative project (Using a wellbeing framework to recognise, value and enhance the broad outcomes for learners in adult literacy and numeracy programmes) elaborating the 2013 work on Māori wellbeing linked to literacy and numeracy instruction (Hutchings, Yates, Isaacs, Whatman, \& Bright, 2013) and ongoing investigation of how literacy practices relate to skills over time (Alkema \& Coben, 2015). As well, further exploration of the numerous creative tutordeveloped informal assessments can enrich sector understanding of literacy and numeracy learning.

\section{References}

Alkema, A., \& Coben, D. (2015). Pilot study: Scoping the development of a measure of adults' literacy and numeracy practices (Final Report prepared for the Ministry of Education). 
Hamilton, NZ: The National Centre of Literacy and Numeracy for Adults and the University of Waikato and Auckland, Heathrose Research.

Barton, D., \& Hamilton, M. (2005). Literacy, reification and the dynamics of social interaction. In D. Barton, \& K. Tusting (Eds.), Beyond communities of practice: Language, power and social context (pp. 14-35). Cambridge: Cambridge University Press.

Benseman, J., \& Sutton, A. (2008). Facing the challenge: Foundation learning for adults in New Zealand. Wellington: Dunmore.

Cantillon, B., \& Van Lancker, W. (2013). Three shortcomings of the social investment perspective. Social Policy and Society, 12(4), 553-564.

Chari, A. (2013). Reification. In B. Kaldis (Ed.), Encyclopedia of philosophy and the social sciences (pp. 803-804). London: Sage.

Do, D., \& Hazlewood, K., with Arnerich, D., \& Gardiner, B. (2016). Literacy and numeracy update. Plenary address presented at the NCLANA 2016 Symposium, Wellington, NZ. Retrieved from https://www.youtube.com/watch?v=Hic2G5RZxZo

Earle, D. (2014). Measures of adult literacy and numeracy: Comparing the adult literacy and life skills survey and the literacy and numeracy for adults assessment tool. Wellington: Ministry of Education.

Fairclough, N. (1989). Language and power. London: Longman.

Fairclough, N. (2003). Analysing discourse. New York: Routledge.

Fenwick, T. (2010). Re-thinking the 'thing': Sociomaterial approaches to understanding and researching learning in work. Journal of Workplace Learning 22(1/2) 104-116. Retrieved from www.emeraldinsight.com/doi/pdfplus/10.1108/13665621011012898

Furness, J. (2012). The contribution of family literacy programmes to the wellbeing of individuals, families and communities (PhD thesis). Hamilton, NZ: Waikato University. Retrieved from http://researchcommons.waikato.ac.nz/

Gee, J. P. (2008). Social linguistics and literacies: Ideology in discourses (3 ${ }^{\text {rd }}$ ed.). London: Routledge.

Hamilton, M. (2016). Imagining literacy: A sociomaterial approach. In K. Yasukawa \& S. Black (Eds.), Beyond economic interests (pp. 3-17). Rotterdam: Sense.

Hamilton, M., \& Barton, D. (2000). The international adult literacy survey: What does it really measure? International Review of Education, 46(5), 377-389.

Hutchings, J., \& Ikin, K. (n.d.). Haea te pū ata: A national strategy for Māori adult literacy and numeracy 2016-2020 (and beyond). Wellington: NZCER.

Hutchings, J., Yates, B., Isaacs, P., Whatman, J., \& Bright, N. (2013). Hei ara ako ki te oranga: A model for measuring wellbeing outcomes from literacy programmes. Wellington: Ako Aotearoa.

Jenson, J. (2009). Redesigning citizenship regimes after neoliberalism. Moving toward social investment. In N. Morel, J. Palier, \& J. Palme (Eds.), What future for social investment? (pp. 27-44). Stockholm: Institute for Futures Studies.

Māori Adult Literacy Working Party. (2001). Te kawai ora: Reading the world, reading the word, being the world. Wellington: Ministry of Māori Development.

Māori Economic Development Panel. (2012). He kai kei aku ringa: The Crown-Maori Economic Growth Partnership: Strategy to 2040. Wellington: Author.

Ministry of Education. (2001). More than words: The New Zealand adult literacy strategy. Wellington, NZ: Author.

Ministry of Education. (2012). The Māori education strategy: Ka Hikitia - Accelerating success 2013 -2017. Wellington: Author. 
Ministry of Business, Innovation and Employment \& Ministry of Education. (2014). Tertiary Education Strategy 2014-2019. Wellington: Author.

OECD \& Statistics Canada. (2000). Literacy in the information age: Final report of the International Survey of Adult Literacy. Paris: Authors.

Pahl, K. (2014). Materialising literacy in communities: The uses of literacy revisited. London: Bloomsbury.

Tertiary Education Commission. (2008). Literacy, language and numeracy implementation plan 2008-2012. Wellington, NZ: Author.

Tertiary Education Commission. (2009). Strengthening literacy and numeracy: Theoretical framework. Wellington, NZ: Author.

Tertiary Education Commission. (2015). Literacy and Numeracy Implementation Strategy 2015-2019. Wellington, NZ: Author.

Thomas, G., Johnston, M., \& Ward, J. (2014). Alignment of literacy and numeracy measures: Research for the Tertiary Education Commission. Dunedin: NZ Maths Technology.

Thorn, W. (2016). New Zealand in the International Survey of Adult Skills (PIAAC). Plenary address presented at the NCLANA 2016 Symposium, Wellington, NZ. Retrieved from https://www.youtube.com/watch?v=8GEOrPGESgl

Treasury. (October 2016) Social investment. Retrieved from http://www.treasury.govt.nz/ statesector/socialinvestment

Walker, M., Udy, K., Pole, N., May, S., Chamberlain, G., \& Sturrock, F. (1997). Adult literacy in New Zealand: Results from the Adult Literacy Survey. Wellington: Ministry of Education.

Jane Furness has recently completed a post-doctoral research fellowship at the Wilf Malcolm Institute of Educational Research, Faculty of Education at the University of Waikato where she is now a Research Fellow. She is also a Research Fellow and Teaching Fellow in the Department of Psychology, Faculty of Arts and Social Sciences. Jane has worked in the area of adult learning and adult and family literacy education for over twenty years with a particular focus on social justice and wellbeing Her doctoral research explored the wellbeing outcomes for individuals, families and communities from adults' participation in family-focused adult literacy programmes.

Email: jane.furness@waikato.ac.nz

Judy Hunter is a Senior Research Fellow at the Wilf Malcolm Institute of Educational Research, the University of Waikato and doctoral supervisor at the University of Waikato Faculty of Education. Her research focuses on understanding how people make sense of their world through language and literacy in use, particularly those from marginalised populations.

Email: judy.hunter@waikato.ac.nz 